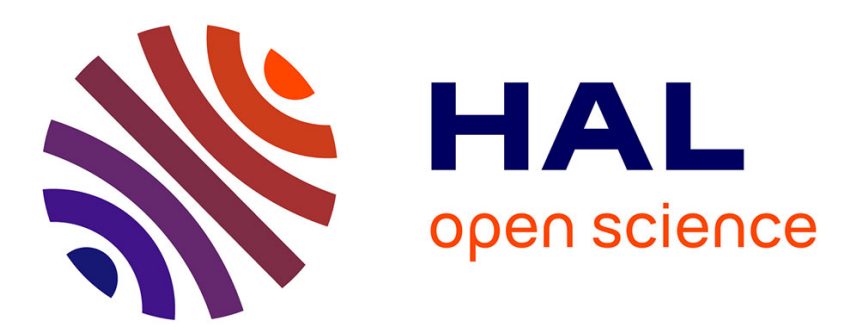

\title{
Occurrence of organic colloids in the stratified estuary of the Krka River (Croatia).
}

\author{
Richard Sempere, Gustave Cauwet
}

\section{To cite this version:}

Richard Sempere, Gustave Cauwet. Occurrence of organic colloids in the stratified estuary of the Krka River (Croatia).. Estuarine, Coastal and Shelf Science, 1995, 40 (1), pp.105-114. 10.1016/02727714(95)90016-0 . hal-01171591

\section{HAL Id: hal-01171591 \\ https://hal.science/hal-01171591}

Submitted on 18 Feb 2019

HAL is a multi-disciplinary open access archive for the deposit and dissemination of scientific research documents, whether they are published or not. The documents may come from teaching and research institutions in France or abroad, or from public or private research centers.
L'archive ouverte pluridisciplinaire HAL, est destinée au dépôt et à la diffusion de documents scientifiques de niveau recherche, publiés ou non, émanant des établissements d'enseignement et de recherche français ou étrangers, des laboratoires publics ou privés. 


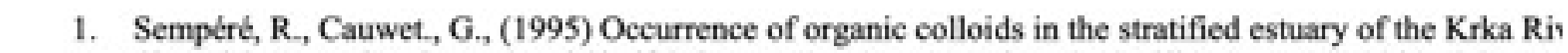

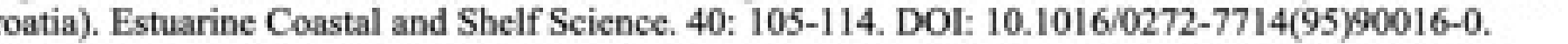




\title{
Occurrence of Organic Colloids in the Stratified Estuary of the Krka River (Croatia)
}

\author{
Richard Sempéré ${ }^{a}$ and Gustave Cauwet \\ Laboratoire de Sédimentologie et Géochimie Marines, CNRS URA 715, Université \\ de Perpignan, 52 Avenue de Villeneuve, 66860 Perpignan Cedex, France \\ Received 18 October 1993 and in revised form 18 fanuary 1994
}

Keywords: colloidal organic carbon; dissolved organic carbon; halocline; Krka Estuary

\begin{abstract}
Along a vertical profile of a stratified estuary, we determined organic carbon in the following fractions: low molecular weight ( $\mathrm{LMW}-\mathrm{OC}<0.02 \mu \mathrm{m}$ ), colloidal $(0.02 \mu \mathrm{m}<\mathrm{COC}<0.7 \mu \mathrm{m}$ ), dissolved (DOC $<0.7 \mu \mathrm{m}$ ) and particulate (POC $>0.7 \mu \mathrm{m})$. The results showed abundant concentrations of organic colloids accounting for: $40 \%$ of total organic carbon (TOC) in the overlying brackish water (salinity 2), $22 \%$ in the underlying marine water (salinity 38 ) and $19 \%( \pm 5 \%)$ for intermediate salinity samples (salinity 3-31). Upon contact with seawater (in the salinity range $2-5$ ) both DOC and COC concentrations decreased drastically ( 44 and $47 \mu M$ respectively), whereas POC slightly increased ( $11 \mu \mathrm{M})$, being consistent with previous laboratory and field studies, and indicating that at low salinities, the colloidal fraction is actively involved in the DOC physicochemical aggregation. In the halocline, we observed that organic colloids and relatively degraded particles accumulated together in the lowest part of the interface (salinity 31). Because previous studies in the same area have shown accumulation of degraded cells and fragments in the bottom of the halocline, we suggest that large colloids (COC in this study) at the interface probably originated from fragmentation of non-living organisms or aggregates. Furthermore, it is likely that these processes which are enhanced in a highly stratified estuary, are partly responsible for the DOC non-conservative dilution observed along this profile.
\end{abstract}

\section{Introduction}

In aquatic environments colloids are defined as material in the range $0.001-1 \mu \mathrm{m}$ (Vold \& Vold, 1983; Goldberg, 1988). Thereby, they comprise a large spectrum of organic and inorganic species including clays, macromolecules, aggregates as well as viruses and some bacteria and flagellates (Sharp, 1973; Cauwet, 1978; Stumm \& Morgan, 1981; Rassoulzadegan \& Sheldon, 1986; Bergh et al., 1989). Although several studies have reported a significant concentration of colloids particularly in particle-rich media such as the oceanic euphotic layer, the coastal or estuarine waters (Sigleo et al., 1982;

${ }^{a}$ Present address: Laboratoire de Microbiologie Marine, CNRS UPR 223, Campus de Luminy Case 907, 13288 Marseille Cedex 9, France. 
Koike et al., 1990; Wells \& Goldberg, 1991; Benner et al., 1992; Ogawa \& Ogura, 1992; Sempéré et al., 1994), very little is known about their distribution and how they might affect biogeochemical processes in natural waters.

However, in the estuary numerous studies reported physicochemical aggregation phenomena of high molecular weight terrigenous-derived dissolved organic matter (DOM) (Sholkovitz, 1976; Mayer, 1985; Whitehouse et al., 1989; Sempéré \& Cauwet, 1993) highlighting a colloid $\rightarrow$ particle transfer which may precede sedimentation (Pauc, 1980; McCave, 1984). On the other hand, it has been proposed that some organic colloids may have originated from fragmentation of particles (Lampert, 1978; Cho \& Azam, 1988; Karl et al., 1988; Koike et al., 1990; Smith et al., 1992; Sempéré et al., $1994)$ indicating in this case a particle $\rightarrow$ colloid pathway. Moreover, recent discoveries indicated possible assimilation of colloidal DOM by choanoflagellates as well as tunicates (Marchant \& Scott, 1993; Tranvik et al., 1993). Therefore, qualifying and quantifying processes involving the colloidal fraction, may help to a better understanding of the microbial food-web as well as the organic matter transfer in estuary.

The highly stratified estuary of the Krka River (Croatia), is well suited for investigations dealing with the transformations of organic matter because different processes such as primary production, degradation of particles by bacteria as well as physicochemical aggregation/disaggregation have been observed along a vertical salinity gradient established in less than $1 \mathrm{~m}$ (Zutic \& Legovic, 1987; Vilicic et al., 1989; Biscan et al., 1991; Cauwet, 1991; Fuks et al., 1991; Legovic et al., 1991 a; Svetlicic et al., 1991). In spring 1990, we simultaneously collected water samples along a vertical profile from the Krka Estuary and analysed them for organic carbon content in the so-called 'low molecular weight ', 'colloidal', 'dissolved' and 'particulate' fractions. By comparison between these parameters and previous studies, we discuss the physicochemical and biological processes which may involve large organic colloids in the size range $0.02-0.7 \mu \mathrm{m}$.

\section{Materials and methods}

In May 1990, seven water samples were collected from the Krka Estuary (Figure 1; station E) above, below and at 4-10-cm intervals vertically in the halocline. For the sampling a scuba diver used a multichannel peristaltic pump which avoids disturbance by air bubbles (Kniewald et al., 1987; Cauwet, 1991). In this study, the halocline which was defined as the interval in which $\triangle S / \triangle Z>5 \mathrm{~m}^{-1}$ (Vukojevic, 1983, cited in Legovic et al., 1991b), separated the upper brackish water layer from the lower marine layer at c. $2 \mathrm{~m}$ below the surface. After collection, the water was filtered under reduced vacuum with an all-glass filter holder through a $47-\mathrm{mm}$-diameter pre-heated $\left(45^{\circ} \mathrm{C}\right)$ glass fibre filter $(\mathrm{GF} / \mathrm{F})$. The filtration was stopped after 11 to avoid colloid adsorption on the filter. The rinsed filters were dried at $40^{\circ} \mathrm{C}$ for $24 \mathrm{~h}$ and were used later for total suspended matter (TSM) and POC determinations, whereas the filtrates were collected in pre-heated $\left(450^{\circ} \mathrm{C}\right)$ graduated glass bottles (1 l ) tightly closed with a Teflon-lined cap.

The subsamples were subsequently ultrafiltered under a laminar flow air bench through a $0.02 \mu \mathrm{m}$ laboratory synthesized tubular membrane of zirconium/aluminium oxide (Larbot et al., 1989) by the method described previously (Sempéré, 1991; Sempéré et al., 1994). The laboratory experiments (with Dextran solutions) indicated that the membrane cutoff was around 500000 dalton. Briefly, 11 of each pre-filtered sample was 1.7 times concentrated by cross-flow ultrafiltration on the membrane 


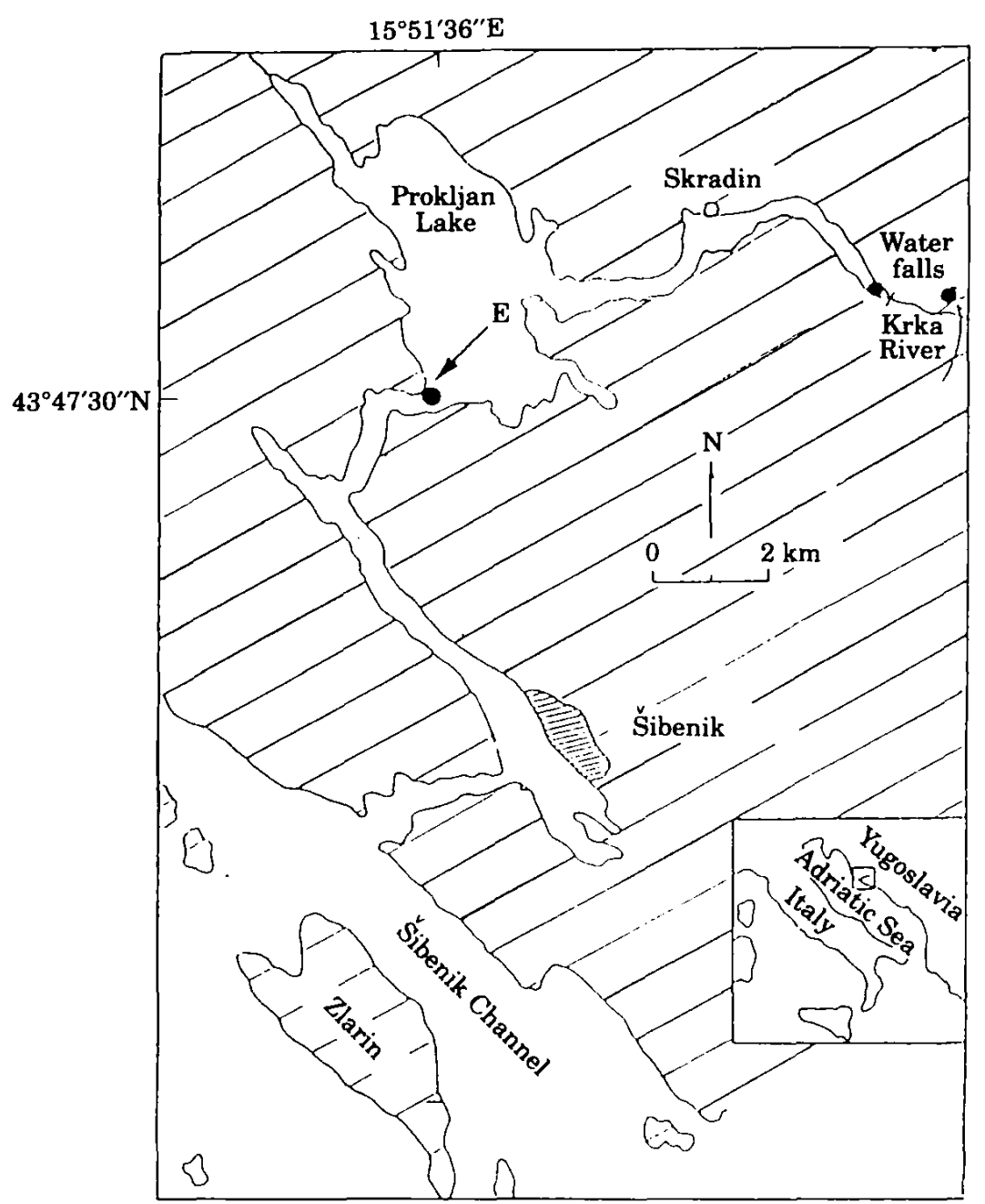

Figure 1. Location of the Krka Estuary (Croatia) and sampling station (E).

inserted in a Teflon/Kel $\mathbf{F}$ unit. These conditions facilitated a good conditioning of the membrane and avoided membrane clogging. Ultrafiltrate and concentrate were collected in pre-heated $\left(450^{\circ} \mathrm{C}\right)$ graduated glass bottles $(1 \mathrm{l})$ and closed with a Teflon-lined cap. Total procedure time for each sample was c. $5 \mathrm{~h}$. Aliquots $(8 \mathrm{ml})$ of filtered and ultrafiltered samples (ultrafiltrate + concentrate) were taken in pre-heated $\left(450^{\circ} \mathrm{C}\right.$ ) $10-\mathrm{ml}$ glass vials poisoned with $\mathrm{HgCl}_{2}\left(10 \mathrm{mg} 1^{-1}\right)$, covered with a Teflon-lined cap, and stored at $4{ }^{\circ} \mathrm{C}$ in the dark. Therefore, by the separative methods described above, organic carbon was operationally fractionated in the following fractions: LMW-OC $<0.02 \mu \mathrm{m} ; 0.02<$ COC $<0.7 \mu \mathrm{m} ;$ DOC $<0.7 \mu \mathrm{m} ;$ POC $>0.7 \mu \mathrm{m}$.

For DOC (ultrafiltrate, concentrate and initial GF/F filtrate) measurements, after acidification ( $\mathrm{pH} 2$ ) with a $2 \mathrm{M} \mathrm{HCl}$ solution, the samples were bubbled for $5 \mathrm{~min}$, with $\mathrm{CO}_{2}$-free pure air to purge inorganic carbon. Dissolved organic carbon was measured by means of the uv-persulphate oxidation method (Collins \& Williams, 1977) modified by Cauwet (1984). The standard deviation was c. $3 \mu \mathrm{M}$ for $<83 \mu \mathrm{M}$ and less than $2 \%$ above. The carbon blank of the water used for the standard solutions $(83,167,250,333 \mu \mathrm{M})$ 
TABLE 1. Depth collection, salinity, particulate organic carbon (POC) and dissolved inorganic carbon (DIC) in water samples collected from the Krka Estuary, May 1990

\begin{tabular}{lcccc}
\hline Depth $(\mathrm{m})$ & Salinity & POC $(\mu \mathrm{M})$ & POC\% & DIC $(\mu \mathrm{M})$ \\
\hline 1.50 & 2 & $48 \pm 1$ & 18 & $3815 \pm 8$ \\
1.90 & 3 & $36 \pm 1$ & 16 & $3931 \pm 8$ \\
1.96 & 5 & $59 \pm 1$ & 17 & $3591 \pm 8$ \\
2.06 & 19 & $82 \pm 2$ & 26 & $3239 \pm 8$ \\
2.08 & 24 & $108 \pm 2$ & 22 & $2951 \pm 8$ \\
2.12 & 31 & $106 \pm 2$ & 20 & $2934 \pm 8$ \\
5.00 & 38 & $32 \pm 1$ & 15 & $2488 \pm 8$ \\
\hline
\end{tabular}

$\mathrm{POC} \%=(\mathrm{POC} \times 100) / \mathrm{TSM}$.

was estimated to be $15 \mu \mathrm{M}$ by pure air circulation inside the system and subtracted from the standards. In this study, COC represented (after volume corrections) the difference between $\mathrm{DOC}_{\text {concentrate }}$ and DOC ultrafiltrate and thus its uncertainty was estimated to c. $4 \mu \mathrm{M}$ from the square root of the sum of the standard deviation calculation. Our uv-persulphate unit might have underestimated DOC values by a factor of $1.0-1 \cdot 2$ (Cauwet et al., 1990a; Sempéré \& Cauwet, 1993; Cauwet, 1994). Dissolved inorganic carbon (DIC) was measured by a uv-persulphate analyser with a standard deviation of $8 \mu \mathrm{M}$. After removal of carbonates, POC was determined by $\mathrm{GF} / \mathrm{F}$ filter combustion (LECO CS 125 analyser) with a standard deviation of $2 \%$.

\section{Results and discussion}

Description of the halocline, particle characteristics

Table 1 gives the physical parameters (depth collection, salinity) as well as DIC and POC concentrations and POC\% [(POC $\times 100) / T S M]$ of the water samples along the profile. The DIC distribution showed a normal (Meybeck, 1982; Cauwet, 1991) conservative behaviour [Figure $2(\mathrm{a}) ; r^{2}=0.96, n=7$ ] establishing confidence in our sampling precision. The POC concentration range was 32-108 $\mu \mathrm{M}$ (average $67 \mu \mathrm{M}$ ) comprising $15-26 \%$ (average $19 \%$ ) of TSM and $21-44 \%$ (average $32 \%$ ) of total organic carbon (TOC). These high POC \% for corresponding TSM data reflect a situation in which aquatic production dominated the charge of the river (Meybeck, 1982; Ittekot, 1988; Cauwet et al., 1990b).

Particulate organic carbon concentrations increased with the salinity from the brackish water to the bottom of the halocline, thus, the strong salinity gradient (from 3 to 31 in $22 \mathrm{~cm}$ ) and particulate content (POC and POC\%) of the profile [Figure 2(b,c)] are in good agreement with those described previously (Zutic \& Legovic, 1987; Cauwet, 1991, and references therein; Legovic et al., 1991a,b). (1) A well-defined halocline (at $c .2 \mathrm{~m}$ below the surface) separating the overlaying brackish water (first sample salinity 2 ) and the underlying marine water (salinity 38). (2) A particle accumulation in the bottom of the halocline (depth $=2.08-2.12 \mathrm{~m}$; salinity $24-31$ ) as a consequence of the density and shear stress barrier (Cauwet, 1991). However, it is important to notice that POC\% maximum (depth $=2.06 \mathrm{~m}$; salinity 19 ) was situated above the POC maximum (depth $=2.08 \mathrm{~m}$; salinity 24 ) indicating that the particles are preferentially degraded in the lowest part of the interface. This later observation is consistent with the results of Zutic and Legovic (1987) and Vilicic et al. (1989) who reported in the bottom of the 


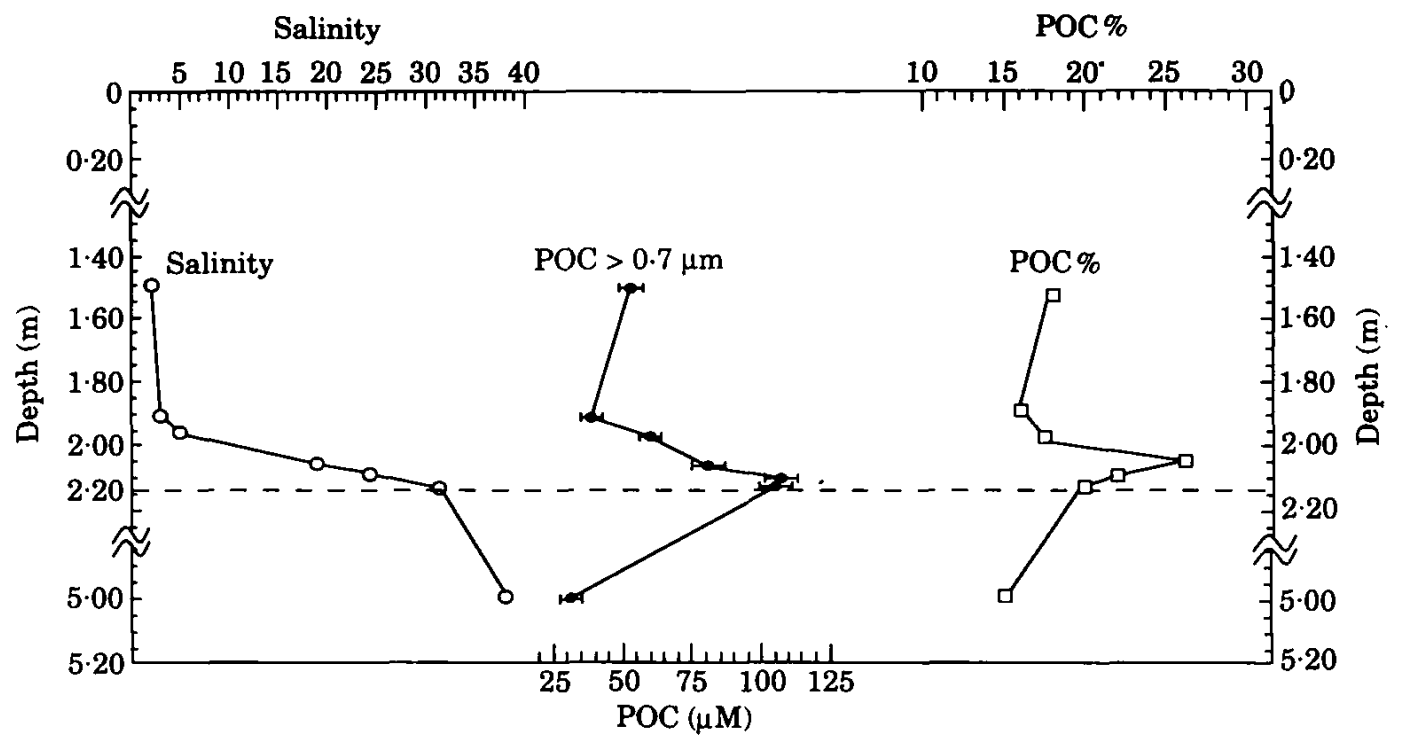

(a)

(b)

(c)

Figure 2. Vertical profiles for (a) salinity, (b) particulate organic carbon $(\mathrm{POC}>0.7 \mu \mathrm{m})$ and (c) organic content of total suspended matter [POC $\%=(100 \times \mathrm{POC}) / \mathrm{TSM}]$. POC standard deviation is within $2 \%$, horizontal error bars are smaller than the symbol size.

TABLE 2. Depth collection, salinity, dissolved organic carbon (DOC), colloidal organic carbon (COC) and low molecular weight organic carbon (LMW-OC) in the water samples collected from the Krka Estuary, May 1990

\begin{tabular}{lcccccc}
\hline Depth (m) & Salinity & DOC $(\mu M)$ & COC $(\mu M)$ & LMW-OC $(\mu M)$ & COC/DOC (\%) & \% Initial DOC \\
\hline 1.50 & 2 & $147 \pm 3$ & $79 \pm 3$ & $75 \pm 2$ & 54 & 108 \\
1.90 & 3 & $134 \pm 3$ & $46 \pm 4$ & $99 \pm 2$ & 34 & 108 \\
1.96 & 5 & $103 \pm 2$ & $32 \pm 3$ & $80 \pm 2$ & 31 & 108 \\
$2 \cdot 06$ & 19 & $147 \pm 3$ & $32 \pm 4$ & $121 \pm 2$ & 22 & 104 \\
2.08 & 24 & $144 \pm 3$ & $40 \pm 4$ & $109 \pm 2$ & 28 & 103 \\
$2 \cdot 12$ & 31 & $133 \pm 3$ & $41 \pm 4$ & $98 \pm 2$ & 31 & 104 \\
5.00 & 38 & $121 \pm 2$ & $33 \pm 4$ & $92 \pm 2$ & 27 & 103 \\
\hline
\end{tabular}

DOC $<0.7 \mu \mathrm{m} ; 0.02<\mathrm{COC}<0.7 \mu \mathrm{m} ; \mathrm{LMW}-\mathrm{OC}<0.02 \mu \mathrm{m}$.

$\%$ Initial $\mathrm{DOC}=\left(\mathrm{DOC}_{\text {ultrafiltrate }}+\mathrm{COC}\right) \times 100 / \mathrm{DOC}_{\text {initial water }}$.

halocline, accumulation of chlorophyll degradation product (phaeophytin) as well as heterotrophic activity, the chlorophyll being produced in the overlying water.

\section{Dissolved and colloidal organic carbon distribution}

Table 2 gives DOC and COC data for the samples. Mass balances measured on the samples indicated that an average of $105 \pm 2 \%$ was found in the concentrate and ultrafiltrate fractions indicating that contamination and loss were minimized during the procedure. Dissolved organic carbon concentrations ranged from 103 to $147 \mu \mathrm{M}$ (average $133 \mu \mathrm{M}$ ) and are similar with those already published (Cauwet, 1991). The COC concentration range was $32-79 \mu \mathrm{M}$ (average $43 \mu \mathrm{M}$ ) being maximum at low 
TABLE 3. Depth collection, salinity, and relative abundance of particulate organic carbon (POC), colloidal organic (COC) and low molecular weight organic carbon (LMW-OC) in the water samples collected from the Krka Estuary, May 1990

\begin{tabular}{lcccc}
\hline Depth (m) & Salinity & POC/TOC (\%) & COC/TOC (\%) & LMW-OC/TOC (\%) \\
\hline 1.50 & 2 & 25 & 40 & 38 \\
1.90 & 3 & 21 & 27 & 58 \\
1.96 & 5 & 36 & 20 & 49 \\
2.06 & 19 & 36 & 14 & 53 \\
2.08 & 24 & 43 & 16 & 43 \\
2.12 & 31 & 44 & 17 & 41 \\
5.00 & 38 & 21 & 22 & 60 \\
\hline
\end{tabular}

POC $>0.7 \mu \mathrm{m} ; \quad$ DOC $<0.7 \mu \mathrm{m} ; \quad 0.02 \mu \mathrm{m}<\mathrm{COC}<0.7 \mu \mathrm{m} ; \quad \mathrm{LMW}-\mathrm{OC}<0.02 \mu \mathrm{m}$; $\mathrm{POC}+\mathrm{DOC}=\mathrm{TOC}$.

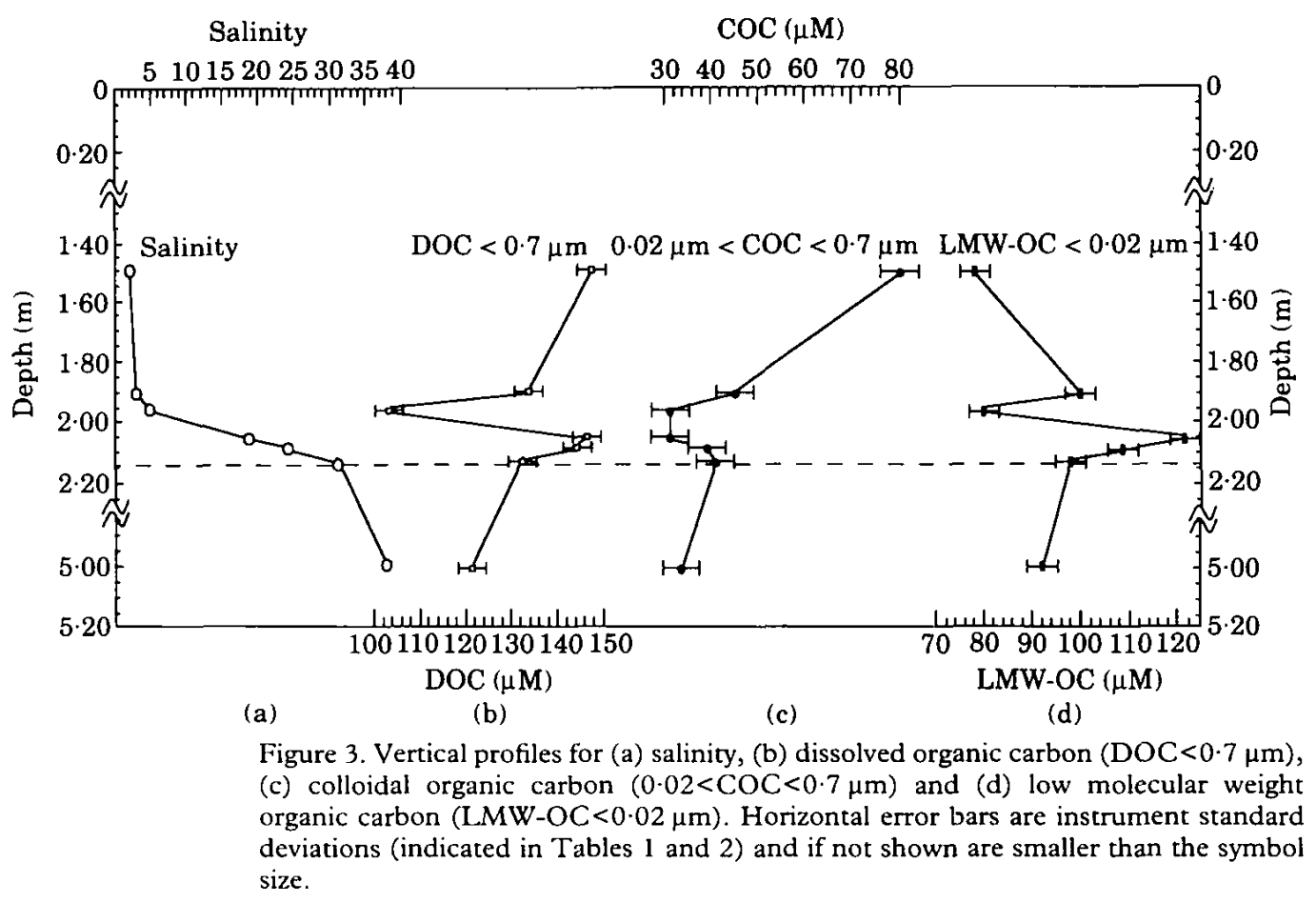

salinity (2); COC comprised $22-54 \%$ (average $32 \%$ ) of DOC (Table 2) and $14-40 \%$ (average $22 \%$ ) of TOC (Table 3), indicating that organic colloids represented a significant fraction of organic carbon during the spring season in the Krka Estuary. Interestingly, the results show a clear non-conservative behaviour of DOC (Figures 3 and 4) as well as COC and LMW-OC (Figure 3), a point which will be discussed later.

In the overlying brackish water the colloidal fraction was relatively the most abundant ( $\mathrm{COC} / \mathrm{DOC}=54 \%$; COC $/ \mathrm{TOC}=40 \%)$. We found that upon contact with seawater (salinity 2-5) the brackish-water DOC decreased sharply by $44 \mu \mathrm{M}$, moreover, Tables 2 , 3 and Figure 3 indicate that this can principally be attributed to its colloidal fraction. This fact has been observed in other estuaries by different authors (Sholkovitz, 1976; 


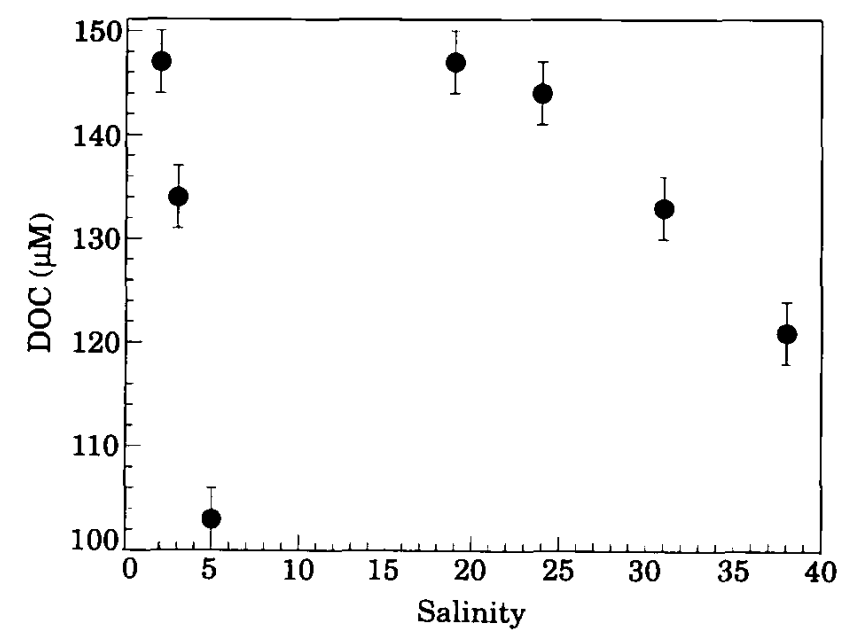

Figure 4. Dissolved organic carbon (DOC) concentration versus salinity for the water samples collected from the Krka Estuary, May 1990. Horizontal error bars are instrument standard deviations (indicated in Table 2).

Whitehouse et al., 1989; Sempéré \& Cauwet, 1993), and certainly reflects the physicochemical flocculation of some terrigenous-derived dissolved organic matter (mainly humic acids) through colloidal state into particles due to ionic strength changes (Sholkovitz, 1976; Mayer, 1985). This phenomenon might explain why we observed [Figure 2(b)] in the salinity 5 sample, a small increase of POC concentration (11 $\mathrm{M})$, the rest of the newly generated particles having probably sunk towards the sediment through the interface. This assumption seems consistent with the previous work of Hadzija et al. (1985) indicating a preferentially terrigenous source of sedimented organic material (rich in carbohydrate-humic substances complexes) in the estuarine sediments. Slightly above the halocline (depth $=2.06 \mathrm{~m}$; salinity 19) we observed a DOC submaximum due to the LMW-OC. It is important to notice that at the same level, we observed the highest organic content of particles [see POC\%, Figure 2(c)]. Although in this study, we do not have simultaneous biological data available, several authors in previous work located the chlorophyll maximum above the halocline as well (Zutic \& Legovic, 1987; Vilicic et al., 1989). If these informations were confirmed together, they may suggest a production of LMW-OC by healthy phytoplankton above the interface.

From the higher part of the halocline (depth $=2.06 \mathrm{~m}$; salinity 19 ) to its lowest part (depth $=2 \cdot 12 \mathrm{~m}$; salinity 31 ), the LMW-OC concentrations decreased slightly from 121 to $98 \mu \mathrm{M}$, whereas COC increased slightly from 32 to $41 \mu \mathrm{M}$. These results showed that at the interface level (depth $=2.12 \mathrm{~m}$; salinity 31 ), organic carbon is in colloidal and particulate states for, respectively, 17 and $44 \%$ (Table 3). Actually, the residence time of particles as well as the number of heterotrophic bacteria in an interface is larger than anywhere else in the water column (Mayer, 1982; Zutic \& Legovic, 1987; Legovic et al., $1991 a)$, then particulate organic matter including dead organisms and also various aggregates, represents a potential source for transformations such as flocculation, disaggregation or DOM releases by organisms. However, it has been reported that in seawater, autolysis of dead cells releases mainly low molecular weight compounds (Carlucci et al., 1984) whereas the ultrafiltration membrane we used in this study, retains mostly large colloids with a molecular weight higher than 500000 dalton (Sempéré et al., 1994). 
Although in estuaries, physicochemical aggregation of dissolved organic matter into colloids induced by seawater usually appears mainly at low salinities (salinity less than 10; Sholkovitz, 1976; Mayer, 1985), we can not totally disregard the flocculation process in saline waters (Baskaran et al., 1992; Moran \& Buesseler, 1992). However, we feel that the apparent increase of organic colloids near the interface may be due to the fragmentation of larger particles by physical disaggregation (Karl et al., 1988) or biological processes (such as micro-organism degradation as well as interspecies grazing; Lampert, 1978; Koike et al., 1990; Smith et al., 1992). Furthermore, Koike et al. (1990) reported that the grazing of bacteria by flagellates in the open ocean is responsible for some submicrometre particle (essentially organic) production. Interestingly, Sigleo et al. (1982) gave a similar composition (30\% carbohydrates, $10 \%$ lipids and $10 \%$ nucleotides) for colloidal material and phytoplankton in the Patuxent River. It is likely that these processes occur together at the interface in proportions difficult to determine.

\section{Non-conservative distribution of $D O C$}

These phenomena may certainly explain partly the clear non-conservative DOC behaviour (Figure $4 ; r^{2}<0 \cdot 1, n=7$ ) along the vertical profile at this season. Several authors have already reported no clear relationship between salinity and DOC (Cauwet, 1991; Suzuki \& Tanoue, 1991; Miller et al., 1993; Sempéré \& Cauwet, 1993). On the other hand, although the flocculation of the colloidal fraction of DOC was generally admitted, DOC conservative dilution has been observed many times (Moore et al., 1979; Mantoura \& Woodward, 1983; Whitehouse et al., 1989). Dissolved organic carbon conservative dilution concept along an estuary is usually related to internal physicochemical and biological processes (Mantoura, 1987). Flowing from a karstic environment, the Krka River generally has clear water and a very low DOC concentration constant throughout the year, therefore, the biological production in the estuary will play an important role in the carbon budget (Cauwet, 1991). However, upon the first contact with seawater, and probably because of the sensitive sampling technique we observed the fate of DOC by physicochemical processes ( $29 \%$ as regard to the theoretical dilution by seawater salinity 5). Moreover, the special character of the interface (which acts as a kind of density barrier) probably contributes to biologically regulate the concentration of colloidal and low molecular weight fractions of DOC slightly above and in the halocline. All these organic matter transformations which in other kinds of estuaries may occur near the sediment or in the bottom nepheloid layer (Sempéré et al., 1994) might firstly not be detected by surface water sampling, and secondly affect the DOC mass balance in the estuary.

\section{Acknowledgements}

This study is part of a French-Yugoslav research programme on stratified estuaries, supported by EEC contract No. CI1-0544-F. We thank D. Petricoli for sample collection, Professors I. Koike, H. Ogawa and N. Ohkuchi from the O. R. I. Tokyo Japan for useful comments on the manuscript, Drs B. Cosovic, N. Vdovic, V. Vojvodic and V. Zutic from the Centre For Marine Research of the Rudjer Boskovic Institute, Zagreb Croatia for helpful discussions. The authors are also very grateful to Manami Motoya and Dr J. Sanderson for the English correction of the manuscript and to the anonymous referees for improving the quality of the manuscript. 


\section{References}

Baskaran, M., Santschi, P. H., Benoit, G. \& Honeyman, B. D. 1992 Scavenging of thorium isotopes by colloids in seawater of the Gulf of Mexico. Geochimica et cosmochimica Acta 56, 3375-3388.

Benner, R., Pakulski, J. D., McCarthy, M., Hedges, J. I. \& Hatcher, P. G. 1992 Bulk chemical characteristics of dissolved organic matter in the ocean. Science 255, 1561-1564.

Bergh, O., Børshein, K. Y., Bratbak, G. \& Heldal, M. 1989 High abundance of viruses found in aquatic environment. Nature 340, 467-468.

Biscan, J., Rhebergen, I., Juracic, M., Martin, J. M. \& Mouchel, J. M. 1991 Surface properties of suspended solids in stratified estuaries (Krka River estuary and Rhône River delta). Marine Chemistry 32, 235-252.

Carlucci, A. F., Craven, D. B. \& Henrichs, S. M. 1984 Diel production and microheterotrophic utilization of dissolved free amino acids in waters off Southern California. Applied and Environmental Microbiology $48,165-170$.

Cauwet, G. 1978 Organic chemistry of sea water particulates. Concepts and developments. Oceanologica Acta 1, 99-105.

Gauwet, G. 1984 Automatic determination of dissolved organic carbon in seawater in the sub-ppm range. Marine Chemistry 14, 297-306.

Cauwet, G. 1991 Carbon inputs and biogeochemical processes at the halocline in a stratified estuary: Krka River, Yugoslavia. Marine Chemistry 32, 269-289.

Cauwet, G. 1994 HTCO method for DOC analysis in seawater: influence of catalyst on blank estimation. Marine Chemistry 47, 55-64.

Cauwet, G., Sempéré, R. \& Saliot, A. 1990 a Carbone organique dissous dans l'eau de mer: confirmation de la sous-estimation antérieure. Comptes Rendus de l'Academie des Sciences Paris 2, 1061-1066.

Cauwet, G., Gadel, F., De Souza Sierra, M. M., Donard, O. F. X. \& Ewald, M. $1990 b$ Contribution of the Rhône River to organic carbon inputs to the North-western Mediterranean Sea. Continental Shelf Research 10, 1025-1037.

Cho, B. C. \& Azam, F. 1988 Major role of bacteria in biogeochemical fluxes in the ocean's interior. Nature $332,441-443$.

Collins, K. H. \& Williams, P. J. LeB. 1977 An automated photochemical method for the determination of dissolved organic carbon in sea and estuarine waters. Marine Chemistry 5, 123-141.

Fuks, D., Devescovi, M., Precali, R., Krstulovic, N. \& Solic, M. 1991 Bacterial abundance and activity in the highly stratified estuary of the Krka River. Marine Chemistry 32, 333-346.

Goldberg, E. D. 1988 Modern chemistry and chemical technology applied to the ocean and its resources. Applied Geochemistry 3, 1-135.

Hadzija, O. Juracic, M., Luic, M., Tonkovic, M. \& Jericevic, B. 1985 The carbohydrates in relation to mineralogic and granulometric composition of surface sediments in the Karst Estuary (River Krka Estuary, Yugoslavia). Estuarine, Coastal and Shelf Science 21, 701-709.

Ittekot, V. 1988 Global trends in the nature of organic matter in river suspensions. Nature 332, 436-438.

Karl, D. M., Knauer, G. A. \& Martin, J. H. 1988 Downward flux of particulate organic matter: a particle decomposition paradox. Nature 332, 438-441.

Kniewald, G., Kwokal, Z. \& Branica, M. 1987 Marine sampling by scuba diving. 3. Sampling procedures for measurement of mercury concentrations in estuarine waters and sea water. Marine Chemistry 22, 343-352.

Koike, I., Hara, S., Terauchi, K. \& Kogure, K. 1990 Role of sub-micrometre particles in the ocean. Nature $345,242-244$.

Lampert, W. 1978 Release of dissolved organic carbon by grazing zooplankton. Limnology and Oceanography 23, 831-834.

Larbot, A., Fabre, J. P., Guisard, C., Cot, L. \& Gillot, J. 1989 New inorganic ultrafiltration membranes: titania and zirconia membranes. Foumal of the American Ceramic Society 72, 257-261.

Legovic, T., Grzetic, Z. \& Zutic, V. 1991 a Subsurface temperature maximum in a stratified estuary. Marine Chemistry 32, 163-170

Legovic, T., Grzetic, Z. \& Smircic, A. 1991 b Effects of wind on a stratified estuary. Marine Chemistry 32, 153-161.

Mantoura, R. F. C. 1987 Organic film at the halocline. Nature 328, 579-580.

Mantoura, R. F. C. \& Woodward, E. M. S. 1983 Conservative behaviour of riverine dissolved organic carbon in the Severn Estuary: chemical and geochemical implications. Geochimica et Cosmochimica Acta 47, 1293-1309.

Marchant, H. J. \& Scott, F. J. 1993 Uptake of submicrometre particles and dissolved organic material by Antarctic choanoflagellates. Marine Ecology Progress Series 92, 59-64.

Mayer, L. M. 1982 Aggregation of colloidal iron during estuarine mixing: kinetics, mechanisms, and seasonality. Geochimica et Cosmochimica Acta 46, 2527-2535. 
Mayer, L. M. 1985 Geochemistry of humic substances in estuarine environments. In Humic Substances in Soil, Sediment, and Water: Geochemistry, Isolation, and Characterisation (McKnight, D. M., ed). Wiley, New York, pp. 211-232.

McCave, I. N. 1984 Size spectra and aggregation of suspended particles in the deep ocean. Deep-Sea Research 31, 329-352.

Meybeck, M. 1982 River transport of organic carbon to the ocean. American foumal of Science 282, $401-450$.

Miller, A. E. J., Mantoura, R. F. C., Suzuki, Y. \& Preston, M. R. 1993 Preliminary study of DOC in the Tamar Estuary, UK, using UV-persulphate and HTCO techniques. Marine Chemistry 41, 223-228.

Moore, R. M., Burton, J. D., Williams, P. J. Le B. \& Young, M. L. 1979 The behaviour of dissolved organic material, iron and manganese in estuarine mixing. Geochimica et Cosmochimica Acta 43, 919-926.

Moran, S. B. \& Buesseler, K. O. 1992 Short residence time of colloids in the upper ocean estimated from ${ }^{238} \mathrm{U}-{ }^{234}$ Th disequilibria. Nature 359, 221-223.

Ogawa, H. \& Ogura, N. 1992 Comparison of two methods for measuring dissolved organic carbon in sea water. Nature 356, 696-698.

Pauc, H. 1980 Flocculation et potentiel de surface des matériaux en suspension et environnement d'embouchure. Comptes Rendus de l'Academie des Sciences Paris 290, 173-175.

Rassoulzadegan, F. \& Sheldon, R. W. 1986 Predator-prey interactions of nanozooplankton and bacteria in an oligotrophic marine environment. Limnology and Oceanography 35, 1010-1021.

Sempéré, R. 1991 Rôle des colloïdes organiques dans les cycles biogeochimiques. Contribution au cycle du 'nouveau carbone'. Mise au point d'une technique d'ultrafiltration tangentielle sur membrane minérale. Ph.D. Thesis, Université de Perpignan, France, 191 pp.

Sempéré, R. \& Cauwet, G. 1993 Dissolved and colloidal organic carbon in the Rhône Estuary: comparison of the UV-persulphate and HTCO method. Comptes Rendus de l'Academie des Sciences Paris 317, 57-63.

Sempéré, R., Cauwet, G. \& Randon, J. 1994 Ultrafiltration of seawater with zirconium and aluminium oxide tubular membrane: application to the study of colloidal organic carbon distribution in the estuarine bottom nepheloid layer. Marine Chemistry 46, 49-60.

Sharp, J. H. 1973 Size classes of organic carbon in seawater. Limonology and Oceanography 18, 441-447.

Sholkovitz, E. R. 1976 Flocculation of dissolved organic and inorganic matter during the mixing of river water and seawater. Geochimica et Cosmochimica Acta 40, 831-845.

Sigleo, A. C., Hoering, T. C. \& Helz, G. R. 1982 Composition of estuarine colloidal material: organic components. Geochimica et Cosmochimica Acta 46, 1619-1626.

Smith, D. C., Simon, M., Alldredge, A. L. \& Azam, F. 1992 Intense hydrolytic enzyme activity on marine aggregates and implications for rapid particle dissolution. Nature 359, 139-141.

Stumm, W. \& Morgan, J. J. 1981 Aquatic Chemistry. 2nd edn. Wiley, New York, 656 pp.

Suzuki, Y. \& Tanoue, E. 1991 Dissolved organic carbon enigma: implications for ocean margins. In Ocean Margin Processes in Global Change (Mantoura, R. F. C. Martin, J. M. \& Wollast, R., eds). Wiley, Chichester, pp. 197-209.

Svetlicic, V., Zutic, V. \& Tomaic, J. 1991 Estuarine transformation of organic matter: single coalescence events of estuarine surface active particles. Marine Chemistry 32, 253-267.

Tranvik, L. J., Sherr, E. B. \& Sherr, B. S. 1993 Uptake and utilization of ' colloidal DOM ' by heterotrophic flagellates in seawater. Marine Ecology Progress Series 92, 301-309.

Vilicic, D., Legovic, T. \& Zutic, V. 1989 Vertical distribution of phytoplankton in a stratified estuary. Aquatic Science 52, 32-46.

Vold, R. D. \& Vold, M. J. 1983 Colloid and Interface Chemistry. Addison-Wesley, Reading, Massachusetts, $694 \mathrm{pp}$.

Wells, M. L. \& Goldberg, E. D. 1991 Occurrence of small colloids in sea water. Nature 353, 342-344.

Whitehouse, B., MacDonald, R. W., Iseki, K., Yunker, M. B. \& McLaughlin, F. A. 1989 Organic carbon and colloids in the Mackenzie River and Beaufort Sea. Marine Chemistry 26, 371-378.

Zutic, V. \& Legovic, T. 1987 A film of organic matter at the fresh water/sea-water interface of an estuary. Nature 328, 612-614. 